\title{
The Effect of Leadership and Individual Characteristics on Work Achievement and Impact on Service Performance In Regency Majalengka
}

\author{
Yeti Kuswati ${ }^{*}$, Tati Hartati ${ }^{* *}$ \\ * Ilmu Administrasi Publik, Universitas Majalengka, Jawa Barat, Indonesia \\ ** Ilmu Administrasi Publik, Universitas Majalengka, Jawa Barat, Indonesia
}

Correspondence Author : yetikuswati60@gmail.com

DOI: 10.29322/IJSRP.11.11.2021.p11917

http://dx.doi.org/10.29322/IJSRP.11.11.2021.p11917

\begin{abstract}
This study aims to improve the performance of the Majalengka Regency Tourism Office through the driving factors are leadership and individual characteristics. This study uses quantitative methods with descriptive and verification analysis techniques, with the target respondents being employees of the Majalengka Regency Tourism Office. The sampling technique used is cluster proportional random sampling. The analysis technique in this study uses path analysis. The results showed that leadership, individual characteristics, work performance, and service performance ranged from good to very good. In contrast, the results of verification research showed that leadership and individual characteristics had a positive effect on work performance, and work performance had a significant effect on service performance.
\end{abstract}

Index Terms- Leadership, Individual Character, Work Performance, and Service Performance

\section{INTRODUCTION}

Cervice is the main task that is essential from the figure of the apparatus, as a servant of the state and public servant. This task has $\checkmark$ been clearly outlined in the fourth paragraph of the preamble of the 1945 Constitution, which covers 4 (four) aspects of the apparatus' main service to the community, namely protecting the entire Indonesian nation and the entire homeland of Indonesia, promoting public welfare, educating the nation's life and implementing world order based on independence and it is clarified again in the Decree of the Minister of Empowerment of State Apparatus No. 63 of 2003, which outlines general guidelines for implementing public services. Service as a process of meeting needs through the activities of others directly is a concept that is always actual in various institutional aspects. Not only in business organizations but has developed more broadly in the order of government organizations (Sinambela, 2006:42-43). The provision of services that meet the standards that have been set is indeed a part that needs to be observed. It is still often felt that the minimum service quality is still far from expectations. The provision of services that meet the standards that have been set is indeed a part that needs to be observed. Currently, it is still often felt that the quality of the minimum service is still far from the expectations of the community and what is even more concerning, the community almost does not understand with certainty about the services that should be received and following standard service procedures by the government. People are also reluctant to complain if they receive bad service; they almost certainly resign themselves to receiving poor service. This kind of reality is driven by the nature of public goods being a government monopoly, especially local government agencies/agencies, and almost no comparison from other parties. Therefore, attention to service performance becomes a vital need in improving service delivery, and improving this performance depends on the quality of its human resources. Human resources are one of the elements that play an important role in achieving an organization's goals. Human resources as organizational assets have control over the progress of an organization and the achievement of the goals set by the organization.

Humans are the most important element in the organization because other elements owned by an organization such as venture capital, raw materials, machines, work methods, time, and other assets can only benefit the organization if humans utilize them. As in research (O et al., 2017; Rodjam et al., 2020), "Human Resources (HR) is the main element of the organization compared to other elements such as capital, technology, and money because humans themselves control others to achieve organizational performance. Humans choose technology, humans who seek capital, humans who use and maintain it, besides humans can be a source of lasting competitive advantage. Therefore, human resource management is very important." Human resources in organizations have a variety of individual characteristics that differ from one another. According to (Stephen P. Robbins, 2013, p. 43), these characteristics consist of biographical characteristics such as age, gender, tenure, and status; abilities such as intellectual abilities and physical and learning abilities. The 
differences in individual characteristics will affect the attitudes and work behavior of members of the organization, which will also affect the performance and job satisfaction of each member of the organization. Performance-related to work performance is important for an organization or company to achieve its goals.

In the context of developing human resources, an employee's work performance in an organization is needed to achieve work performance for the employees themselves and the company's success. Work performance is a function of motivation and the ability to complete a task or job. A person should have a certain degree of willingness and level of ability. A person's willingness and skills are not effective enough to do something without a clear understanding of what and how to do it. Work performance is a real behavior displayed by everyone as employees produce work performance according to their role in the agency. Employee performance is a very important thing in the agency's efforts to achieve goals. Work performance is the quality and quantity of an individual or group work (output) in a particular activity caused by natural abilities or abilities obtained from the learning process and the desire to perform better. Work performance is all actions or behaviors controlled by individuals and contribute to the achievement of goals. Furthermore, in addition to individual characteristics, other factors that can affect work performance in the organization are now a leader's leadership in the organization. Leadership is also closely related to the success of achieving good performance in an organization. One's leadership more or less influences the success of achieving organizational goals in the organization. (Blanchard \& Speed, n.d.) defines leadership as an activity that influences people to work together to achieve some desired goal. Several studies (Di et al., 2015; Makambe \& Joy Motlatsi Moeng, 2020; Rukmana, 2020) explain that leadership style strongly influences the progress and decline of performance. Leadership in an organization is a driving force forward in achieving the vision and mission of the organization. Leadership is an important management function. Leading means creating a shared culture and values, communicating goals to employees throughout the organization, and providing input for employees to have higher levels of performance (Y. A. Setiawan et al., 2014; Y. A. C. Setiawan et al., 2014). Based on the above background, which is associated with the fundamental importance of the performance of the Puskesmas to improve public health services. So researchers are encouraged to conduct research studies with the title of research: The Influence of Leadership and Individual Characteristics on work performance and their impact on Service Performance of the Tourism and Culture Office of Majalengka Regency.

\section{LITERATURE REVIEW}

\section{a. Leadership}

Leadership is more than just a set of skills and expertise. Leadership has subtle personal qualities that are a little hard to see but very influential. According to (Purcarea et al., 2009), understanding leadership is "the way a leader influences the behavior of subordinates, so they want to work together and work productively to achieve organizational goals." Meanwhile, according to (Van Dierendonck et al., 2004), "Leadership is a mutually influencing relationship between leaders and subordinates who want real changes that reflect their common goals." Leadership in research (Fatokun et al., 2010) is "the activity of influencing people so that they like to try to achieve group goals." From some of the notions of leadership put forward by several experts above, it can be concluded that leadership is an activity to influence others and change behavior to achieve common goals.

Indicators of leader behavior according to Path-Goal theory (Goswami et al., 2014), including Directive Leadership, namely the leader informs subordinates what is expected of them, informs the work schedule that must be adjusted and work standards, and provides guidance/direction specifically about ways to complete the task, including aspects of planning, organization, coordination, and supervision. Supportive Leadership is a leader who is friendly and shows concern for the needs of subordinates. He also treats all subordinates equally and points out their existence, status, and personal needs to develop satisfying interpersonal relationships among group members. Supportive has a great influence on the performance of subordinates when they are experiencing frustration and disappointment. Participative Leadership is a participatory leader who consults with subordinates and uses their suggestions and ideas before deciding. Participative Leadership can increase the work motivation of subordinates. Achievement-Oriented Leadership is a leadership style in which the leader sets challenging goals and expects subordinates to excel as much as possible. It constantly seeks achievement development in the process of achieving these goals.

\section{b. Individual Characteristics}

The most important resource in an organization is human resources, people who provide their energy, talent, creativity, and effort to the organization to continue to exist. Every human being has individual characteristics that differ from one another. The future of an individual in the organization does not depend on performance alone. Managers also use subjective measures that are judgmental. What is perceived by the rater as a good or bad employee character/behavior will affect the appraisal, according to (Thoha, 2007, p. 34), related to individual characteristics that individuals bring into the organizational structure, abilities, personal beliefs, expectations, needs, and past experiences. These are all characteristics possessed by individuals, and these characteristics will enter a new environment, namely the organization. Meanwhile, Bashaw \& Grant in the (Nur Hayati, 2014) suggested several personal characteristics, including gender, marital status, age, education, family income, and tenure. Meanwhile, according to (Ravichandran et al., 2017), individual characteristics are biographical characteristics, personality, perceptions, and attitudes. 
ISSN 2250-3153

According to (Stephen P. Robbins, 2013, p. 56), Indicators of individual characteristics, including the location of Control (Locus of Control), which is related to individual beliefs about determining results. Individuals who have internal control believe that the results (rewards) are based on their efforts. Meanwhile, those who tend to place external control believe that forces outside their control their results. Internal people tend to prefer a participative leadership style, while external people generally prefer a directive style. Willingness to Accept Influence (Authoritarianism) the influence of others. Subordinates with a high level of authoritarianism tend to respond to a directive leadership style, while subordinates with a low level of authoritarianism tend to choose a participatory leadership style. Abilities, namely the ability and experience of subordinates, will affect whether they can work more successfully with an achievementoriented leader who has defined challenging goals to be achieved and expects high achievement or a supportive leader who prefers to encourage and direct them. Subordinates with high abilities tend to choose an achievement-oriented leadership style, while subordinates with low abilities tend to choose supportive leaders.

\section{c. Work Achievement}

The most important goal of management is to achieve maximum results efficiently and effectively. Thus, every leader in each organizational unit wants every employee to be able to carry out and complete the tasks or work assigned to him following what has been determined is the employee's work performance because the concept of work performance generally measures the work that has been achieved by meeting certain requirements. (Hasibuan, 2006, p. 94) is: "Work achievement is a result of work achieved by a person in carrying out the tasks assigned to him based on skills, experience, and sincerity and time." (Anwar Prabu Mangkunegara, 2015, p. 9) are: "Work achievement is the result of work in quality and quantity achieved by an employee in carrying out his duties following the responsibilities given to him." (Marihot Tua Efendi Hariandja, 2002, p. 194) put forward a definition of work performance, that: "Work performance is a performance which is the result of work produced by employees or real behavior that is displayed following its role in the organization." From the experts' opinions above, it can be concluded that work performance is work achieved by a person in quality and quantity in carrying out the tasks assigned to him based on skills, experience, sincerity, and time.

The elements of work performance that each organization will assess are not always the same. Still, the assessed elements include things expressed by (Hasibuan, 2006, p. 96), including loyalty, namely the assessor measuring employee loyalty to his work, position, and organization. This loyalty is reflected by the willingness of employees to maintain and defend the organization inside and outside of work from the undermining of irresponsible people. Work results, namely the appraiser assesses the work both quality and quantity that the employee can produce from his job description. Honesty, namely, the assessor assesses honesty in carrying out his duties to fulfill the agreement both for himself and for others such as his subordinates. Discipline, namely, the assessor assesses the discipline of employees in complying with existing regulations and doing their work following the instructions given to them. Creativity, namely, the assessor assesses the ability of employees to develop their creativity to complete their work so that they work more efficiently and effectively. Cooperation, namely, the assessor assesses the willingness of employees to participate and cooperate with other employees vertically or horizontally inside and outside the work so that the work will get better.

Leadership is assessing the ability to lead, influence, have a strong personality, be respected, authoritative, and motivate other people or their subordinates to work effectively. Personality: The assessor assesses employees from behavioral attitudes, politeness, cheerfulness, likes, gives a pleasant impression, shows a good attitude, and looks sympathetic and reasonable. The initiative, namely the assessor, assesses the ability to think that is original and based on his initiative to analyze, assess, create, give reasons, get conclusions, and make decisions to solve the problems he faces. Skills, i.e., the rater assesses the employee's ability to integrate and harmonize the various elements involved in policymaking and management situations. Responsibilities in work, namely the appraiser, assess employees' willingness to be responsible for their policies, work, work results, facilities and infrastructure used, and work behavior.

\section{d. Service Performance}

According to Levine quoted by (Atmoko, 2004, p. 78) in his paper on Standard Operating Procedures and Performance Accountability of Government Agencies, he suggests three concepts that can be used to measure the performance of public organizations, namely: Responsiveness: describes the ability of public organizations to carry out their missions and its purpose is primarily to meet the needs of the community. Responsiveness assessment is based on organizational and community data; organizational data is used to identify types of organizational activities and programs, while service user community data is used to identify community demands and needs. Responsibility: implementing public organization activities is carried out following correct administrative principles or following organizational policies, either implicit or explicit. Responsibility can be assessed from the analysis of documents and reports on organizational activities. The assessment is carried out by matching the implementation of the organization's activities and programs with administrative procedures and provisions. Accountability: refers to how much the company's policies and activities are subject to political officials appointed by the people. Accountability data can be obtained from various sources, such as assessments from people's representatives, political officials, and the community.

Etymologically, the word performance means something to be achieved; the achievements are shown, the ability to work. In the Contemporary English Indonesia Dictionary, performance is used when someone carries out a process skillfully following existing procedures and provisions. According to (Sariyanti, 2012), the proper understanding of performance is the quality and quantity of tasks, whether carried out by individuals, groups, or organizations. Performance is always a sign of the success of an organization and the people in the organization. Performance can be seen from various perspectives depending on the goals of each organization, for example, for-profit or for customer satisfaction, and depending on the form of the organization itself (e.g., public, private, business, social, and religious organizations). (Damayanti, 2015, p. 50) states that: performance is the level of task execution that a person, unit can achieve or division using existing capabilities and established boundaries to achieve organizational/company goals. Meanwhile, according to

This publication is licensed under Creative Commons Attribution CC BY.

http://dx.doi.org/10.29322/IJSRP.11.11.2021.p11917

WwW.ijsrp.org 
(Sedarmayanti, 2014, p. 50): "Performance is a translation of performance which means work performance, work implementation, work achievement, work performance or work appearance."

According to (Gomes, 1999, pp. 159-160), performance is often associated with productivity, which indicates the risk of inputs and outputs in the organization. Performance can even be seen from the point of view of performance by emphasizing the value of efficiency associated with the quality of output produced by employees based on several standards that have been previously set by the organization concerned. According to (Dharma 1991, p. 1), the definition of performance is "performance instead of work achievement is something that is produced or products or services produced or provided by a person or group of people." To assess the effectiveness or performance, Gibson in (Sahertian, 1998) states that "The assessments we make are following the achievements of individuals, groups, and organizations the closer they are to the expected performance the more effective we assess them."

Gibson in (Sahertian, 1998) argues that as a prerequisite for the formation of high Performance is a change in positive attitudes and behavior. Some provide an understanding of Performance as the implementation of a function, as stated by (Whitmore 1997, p. 104), "Performance is the implementation of functions that are required of a person. Performance can also be interpreted as the results or achievements achieved by individuals, units, organizations that have outputs, namely quality and quantity or The Degree Of Accomplishment. To find out the achievements of an organization requires a measure or criteria as an indicator of success. Berman (Keban 2008, p. 209) defines Performance as "Efficient and effective use of resources to achieve results." According to Pollit and Bouckaert (Keban 2008, p. 209) stated that in practice, performance measurement was developed extensively, intensively, and externally. Extensive performance development implies that more areas of work are included in performance measurement. Intensive performance development means that more management functions are included in performance measurement, while external development means more external parties are taken into account.

\section{RESEARCH METHODS}

The research method used here is a survey method. This research is an administrative science approach, especially leadership, individual characteristics, work performance, and service performance. This study uses descriptive and verification analysis because the implementation includes data, analysis, and interpretation of the meaning and data obtained. The types and sources of data collected in this study are (1) primary data: data directly obtained from respondents through questionnaires, interviews, and observations collected by researchers, (2) secondary data: data that supports primary data obtained from documents. The sampling criteria must meet several conditions; namely, the sample taken must be able to provide a reliable picture of the population as a whole, can determine the precision, namely the level of determination determined by the difference in results obtained from complete records, provided that the circumstances in which both methods are carried out the same, simple so that it is easy to implement, can provide maximum results with minimal cost risk. The staffing data found that the number of civil servants is 28 people, and 12 people are non-civil servants so that the total population is 40 . Because the population is below 100 , all of them were sampled in this study, so the sampling technique used was census or total sampling.

Based on identifying the problem, research objectives, and hypotheses, the analysis design used is the path analysis method. This analysis aims to determine the magnitude of the influence of a variable on other variables, whether it is a direct or indirect influence, and to measure the magnitude of the influence of a causal variable to an effect variable called the path coefficient. Considering that the data obtained is ordinal while data analysis requires interval data. The raw data that has been collected first is transformed into interval data through the successive interval method. The reason for using path analysis in this study is based on the model built by the researcher, which allows it to be suitable for analysis using the path analysis method. This was done because the researcher wanted to know more deeply about the magnitude of the influence of leadership variables and individual characteristics on work performance and their impact on service performance, either directly or indirectly.

\section{RESEARCH RESULTS AND DISCUSSION}

Analysis of the description of the variables in the study was seen from the value of the frequency distribution, the average value, and the continuum line. The results of the description analysis can be seen as follows.

Table 1. Descriptive Analysis of Research Variables

\begin{tabular}{lllll}
\hline No & Variable & Score & Average & Category \\
\hline 1 & Leadership & 320 & 4.48 & High \\
2 & Individual characteristics & 240 & 4.36 & Very High \\
3 & Work Achievement & 634 & 4.49 & Very High \\
4 & Service Performance & 562 & 4.10 & High \\
\hline
\end{tabular}

This publication is licensed under Creative Commons Attribution CC BY.

http://dx.doi.org/10.29322/IJSRP.11.11.2021.p11917

www.ijsrp.org 
The study results on the leadership of the head of the service were descriptively analyzed through the value of the frequency distribution. The average value was in the high category; this was seen from acquiring a score of 4.48 , which was included in the high category. Another finding is that the fulfillment of the needs of employees in the completeness of facilities and infrastructure that support the work is still being pursued to make improvements considering that the facilities and infrastructure that support the implementation of the work are considered vital in their position. However, the facilities and infrastructure are currently considered sufficient, but with developments and dynamics, facilities and infrastructure allow for updates to keep pace with the current dynamics. Based on the research results on individual characteristics, variables have an average value of 4.36, which is included in the high category. The high value is strongly influenced by indicators of employee compliance and employee openness attitudes. These two indicators are empirically a supporting factor in shaping the characteristics of quality employees. With these findings, employees in the Department of Tourism and Culture have good personalities, especially in the openness and compliance of employees. However, there are still indicators that need to be improved regarding the internal control factors for employees, which employees judge to be not in line with employee expectations. Internal control factors in this study are intended to assess aspects of employee career development and employee competency improvement that need to be considered by the leadership.

Based on the results of the work performance variable analysis, based on the frequency distribution and the average value included in the high category. This can be seen from the average value of 4.10. From the analysis results, it is found that the indicator of maintaining organizational resources is considered the highest compared to other indicators. These results indicate that service performance in maintaining and caring for all assets owned by the organization, especially those related to service aspects, is considered good. However, several aspects reflect work performance that is not as expected, including the completion of quantity in work and employee attitudes that are considered necessary. An increase is made; this empirically shows that employees are not fully optimized in terms of work motivation, which is the cause of the flow indicator. Based on the analysis of service performance based on descriptive analysis, an average value of 42.0 was obtained, which was included in the high category. This finding provides empirical facts that the services provided by the Department of Tourism and Culture are considered good by employees, especially in assessing the standard operating procedure system indicators that employees have firmly held in providing services as well as regarding the clarity of service requirements and the certainty of officers in providing services. . Meanwhile, other findings that are considered to need still to be improved are regarding the service time, which sometimes there are still delays in the service completion process. The results of the recapitulation of path analysis using the SPSS Version 20.0 program can be seen in the image below:

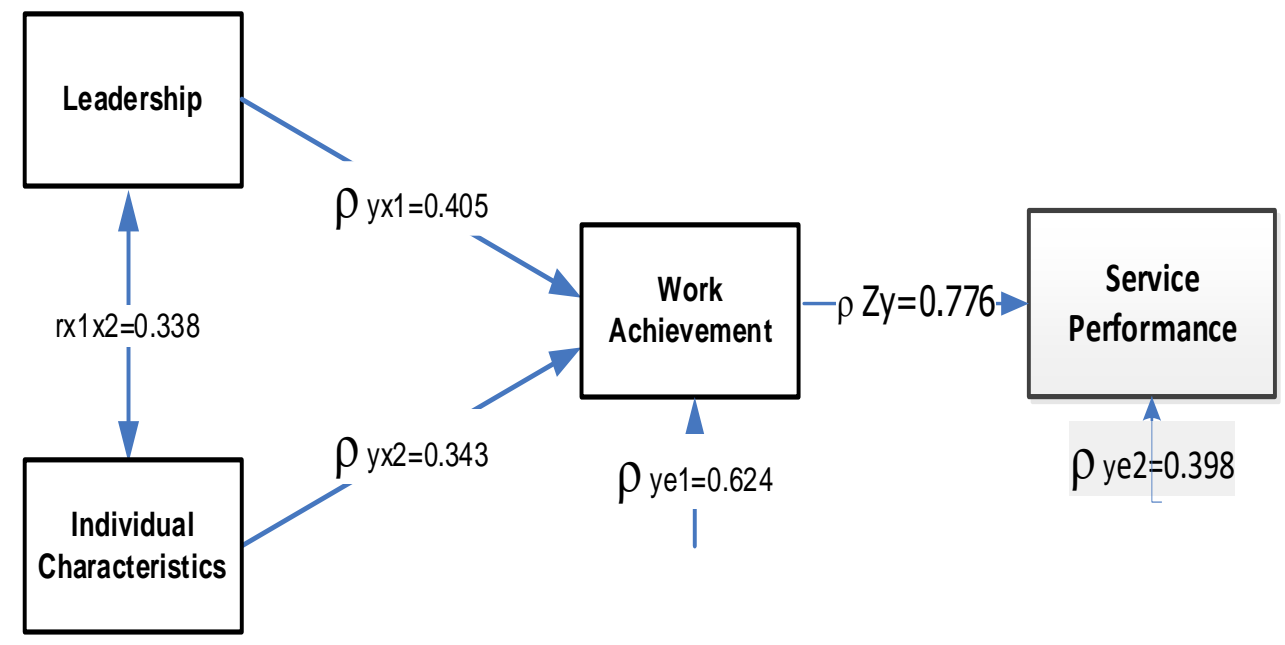

Figure 1. Results of Analysis of All Research Models

Source : research data

Based on the picture above shows that the model built by the researcher is based on 3 foundations, namely the normative, theoretical, and empirical basis; after testing the model, it is interpreted that the model has been scientifically tested and meets the rules of quantitative research methodology so that the company can implement the model to improve service performance. Path coefficient analysis for substructure 1 is the leadership variable of the head of the service and individual characteristics on work performance based on the perceptions of respondents who have been used as research samples which will later be generalized to the research population. The results of processing path analysis using the SPSS version 20.0 program are described as follows: 
Table 2. Path Coefficient of the Leadership Variables and Individual Characteristics

\begin{tabular}{|c|c|c|c|c|c|c|}
\hline \multicolumn{7}{|c|}{ Coefficients $^{a}$} \\
\hline \multirow{2}{*}{\multicolumn{2}{|c|}{ Model }} & \multicolumn{2}{|c|}{ Unstandardized Coefficients } & \multirow{2}{*}{$\begin{array}{c}\begin{array}{c}\text { Standardized } \\
\text { Coefficients }\end{array} \\
\text { Beta }\end{array}$} & \multirow[b]{2}{*}{$\mathrm{t}$} & \multirow[b]{2}{*}{ Sig. } \\
\hline & & $B$ & Std. Error & & & \\
\hline \multirow[t]{3}{*}{1} & (Constant) & 2.418 & .548 & & 4.411 & .000 \\
\hline & $\mathrm{X} 1$ & .222 & .079 & .405 & 2.809 & .008 \\
\hline & $\times 2$ & .297 & .125 & .343 & 2.385 & .023 \\
\hline
\end{tabular}

a. Dependent Variable: $Y$

Source : research data

Based on Table 2 it can be seen that the path coefficient value for the leadership variable of the head of the service is 0.405 , and the individual characteristic variable is 0.343 . An explanation of the value of the coefficient of determination is described in Table 4.32 as follows:

Table 3 Coefficient of Determination Table

Model Summary

\begin{tabular}{|l|l|r|r|r|}
\hline Model & R & R Square & $\begin{array}{c}\text { Adjusted R } \\
\text { Square }\end{array}$ & $\begin{array}{c}\text { Std. Error of } \\
\text { the Estimate }\end{array}$ \\
\hline 1 & $.613^{\mathrm{a}}$ & .376 & .339 & .39355 \\
\hline
\end{tabular}

a. Predictors: (Constant), X2, X1

Source : research data

Based on Table 3, it can be explained that the coefficient of determination for both variables (leadership and individual characteristics) is 0.376 , and other factors outside the research model explain the remaining 0.624 . The direct influence given by the leadership variable on work performance is $16.40 \%$. The direct effect given by the individual characteristic variable on work performance is $11.76 \%$. The indirect effect given by leadership on work performance through individual characteristics is $4.69 \%$. The indirect effect given by individual characteristics on work performance through leadership is $4.69 \%$. The real direct influence given by the leadership variable on work performance is $21.09 \%$. The findings of this study are in line with research conducted (Nawoseing'ollan \& Roussel, 2017; Rozi et al., 2020) that in their research, leadership significantly influences work performance. The total direct effect given by the individual characteristic variables on work performance is $16.45 \%$. This is in line with research conducted (Adam \& Nurdin, 2019; Ilhami et al., 2020; Wahyunanti et al., 2018), which empirically proves that individual characteristic factors significantly affect employee performance. The leadership variable gives the influence, and individual characteristics on work performance simultaneously are 37.54\%. The results of this study are in line with (Adamy et al., 2018; Hidayah, 2012, 2012), which shows that leadership factors and individual characteristics have a simultaneous influence on work performance.

The influence given by other variables outside the research is $62.46 \%$. Based on the path analysis results above, the recap of path analysis calculations based on direct and indirect effects for the first construct, namely the influence of leadership and individual characteristics on work performance, can be seen in the following table. Based on these calculations, it can be informed that the biggest influence that affects work performance is the leadership variable, with a dominant influence of $21.09 \%$ on work performance. In comparison, individual characteristics only influence $16.45 \%$. The real influence of these two variables is $37.54 \%$, and other variables outside the study influence the remaining $62.46 \%$. These results provide empirical facts that leadership factors play a vital role in an organization. These roles include providing motivation, guidance, supervision, and evaluation of their employees to be controlled systematically. With control from the leadership, employees will be motivated to compete in improving their performance. 


\section{CONCLUSION}

The research results on the leadership of the head of the service descriptively included in the high category. Another finding found that the fulfillment of the needs of employees in the completeness of facilities and infrastructure that support the work is still not optimal so that efforts are needed to improve considering that the facilities and infrastructure that support the implementation of the work are considered very vital in their position. However, currently, the facilities and infrastructure are considered sufficient, but Current developments and dynamics of facilities and infrastructure allow for updates to keep pace with current dynamics. The results of research on individual characteristics are descriptively included in the high category. The high value is strongly influenced by indicators of employee compliance and employee openness attitudes. These two indicators are empirically a supporting factor in shaping the characteristics of quality employees. However, there are still indicators that need to be improved regarding the internal control factors for employees, which employees judge to be not in line with employee expectations. Internal control factors in this study are intended to assess aspects of employee career development and employee competency improvement that need to be considered by the leadership.

The results of research on work performance descriptively are included in the high category. These results indicate that service performance in maintaining and caring for all assets owned by the organization, especially those related to service aspects, is considered good. However, several aspects reflect work performance that is not as expected, including the completion of quantity in work and employee attitudes that are considered necessary. An increase is made; this empirically shows that employees are not fully optimized in terms of work motivation, which is the cause of the flow indicator. The results of research on service performance descriptively are included in the high category. This finding provides empirical facts that the services provided by the Department of Tourism and Culture are considered good by employees, especially in assessing the standard operating procedure system indicators that employees have firmly held in providing services as well as regarding the clarity of service requirements and the certainty of officers in providing services. . Meanwhile, other findings that are considered to need still to be improved are regarding the service time, which sometimes there are still delays in the service completion process. Based on the results of hypothesis testing, it is empirically proven that leadership factors influence work performance. Hypothesis testing is proven empirically that individual characteristic factors influence work performance. The results of hypothesis testing are empirically proven that leadership factors and individual characteristics affect work performance. The results of hypothesis testing are empirically proven that work performance factors influence service performance.

\section{REFERENCES}

1. Adam, I. M., \& Nurdin, R. (2019). The Influence of Individual Characteristics, Organizational Characteristics and Work Environment on Employee Performance and Its Impact on the Performance of Bkkbn Representative Organization of Aceh Province. International Journal of Business and Social Science, 10(5), 95-107. https://doi.org/10.30845/ijbss.v10n5p10

2. Adamy, M., Lumbanraja, P., Lubis, A. N., \& Siahaan, E. (2018). The Influence of Individual Characteristics and Transformational Leadership Style on Job Satisfaction and Employee Performance at Bank Aceh Sharia. January 2018. https://doi.org/10.2991/ebic-17.2018.51

3. Anwar Prabu Mangkunegara. (2015). Sumber Daya Manusia Perusahaan. Remaja Rosdakarya.

4. Atmoko, T. (2004). Standar Operasional Prosedur (SOP) dan Akuntabilitas Kinerja Instansi Pemerintah (Issue 7, pp. 1-14).

5. Blanchard, A. K., \& Speed, T. (n.d.). Leading by Influence. http://training.hr.ufl.edu/resources/LeadershipToolkit/job_aids/Leadingbylnfluence.pdf

6. Damayanti, K. (2015). Pengaruh Motivasi, Disiplin, dan Stres Kerja terhadap Kinerja Pegawai Puskesmas di Kecamatan Ponggok Kabupaten Blitar. Jurnal Kompilasi Ilmu Ekonomi, 6(1), 40-52.

7. Di, K., Sulut, B., \& Likupang, K. C. P. (2015). the Influence of Leadership Style, Motivation, and Work Discipline on Employee Performance At Bank Sulut Kcp Likupang. Jurnal EMBA: Jurnal Riset Ekonomi, Manajemen, Bisnis Dan Akuntansi, 3(4), 611619. https://doi.org/10.35794/emba.v3i4.11089

8. Fatokun, J. O., Salaam, M. O., \& Ajegbomogun, F. O. (2010). The influence of leadership style on the performance of subordinates in Nigerian libraries. Library Philosophy and Practice, 2010(SEPTEMBER), 1-8.

9. Gomes, F. . (1999). Manajemen Sumber Daya Manusia : Edisi 3. Andi Offset.

10. Goswami, A., Li, M., Beehr, T. A., \& Goffnett, S. P. (2014). Path-Goal Leaders' Behaviors and Subordinates' Personalities: Resulting Subordinates' Behaviors. Academy of Management Proceedings, 2014(1), 11888-11888.

This publication is licensed under Creative Commons Attribution CC BY. 
https://doi.org/10.5465/ambpp.2014.11888abstract

11. Hasibuan, M. S. P. (2006). Manajemen sumber daya manusia. Bumi Aksara.

12. Hidayah, A. K. (2012). The Influence Of Individual Characteristics, and Leadership, Through Work Motivation and Job Statisfaction On Employee Performance Of East Kalimantan Forestry Agency Office. Jurnal International of Accounting, Finance, and Economics, 1(December), 1-14.

13. Ilhami, S. D., Armanu, A., \& Noermijati, N. (2020). The impact of individual characteristics towards employee performance of millennial employees. International Journal of Research in Business and Social Science (2147-4478), 9(4), 323-329. https://doi.org/10.20525/ijrbs.v9i4.758

14. Makambe, U., \& Joy Motlatsi Moeng, G. (2020). The effects of leadership styles on employee performance: a case of a selected commercial bank in Botswana. Annals of Management and Organization Research, 1(1), 39-50. https://doi.org/10.35912/amor.v1i1.274

15. Marihot Tua Efendi Hariandja. (2002). Manajemen Sumber Daya Manusia. Gramedia Widia Sarana Indonesia.

16. Nawoseing'ollan, D., \& Roussel, J. (2017). Influence of Leadership Styles on Employees' Performance: A Study of Turkana County, Kenya. International Journal of Business and Social Science, 8(7), 82-98. www.ijbssnet.com

17. Nur Hayati, I. C. S. (2014). Pengaruh Karakteristik Individu (Individual Characteristic) dan Karakteristik Tim (Characteristics Team) terhadap Kinerja Tim (Performance Team) (Studi pada Karyawan Bagian Marketing PT. Srikandi Diamond Motor). Jurnal Sains Manajemen \& Akuntansi, VI(1), 1-22.

18. O, O. A., F, O. F., \& A, A. (2017). Human Resource Management and Employee Performance in Federal University of Technology Akure. IOSR Journal of Business and Management, 19(04), 95-104. https://doi.org/10.9790/487x-19040295104

19. Purcarea, A. A., Fleaca, E., \& Dumitriu, D. (2009). The Influence of Leadership on Employees' Behavior. Bulletin of University of Agricultural Sciences and Veterinary Medicine Cluj-Napoca: Horticulture, 66(2), 401-406. https://doi.org/10.15835/buasvmcn-hort:4375

20. Ravichandran, H., Janakiraman, B., Sundaram, S., Fisseha, B., \& Yitayeh, A. (2017). Active Release Technique in Hamstrings Strain : Rehabilitation and Return to Play - A Case Study. 71-74. https://doi.org/10.4103/amhs.amhs

21. Rodjam, C., Thanasrisuebwong, A., Suphuan, T., \& Charoenboon, P. (2020). Effect of human resource management practices on employee performance mediating by employee job satisfaction. Systematic Reviews in Pharmacy, 11(3), 37-47. https://doi.org/10.5530/srp.2020.3.05

22. Rozi, A., Agustin, F., Hindriari, R., Rostikawati, D., \& Akbar, I. R. (2020). The Effect of Leadership on Employee Performance at PT. Stella Satindo in Jakarta. Humanities, Management and Science Proceedings, 1(1), 55-61.

23. Rukmana, I. J. (2020). The Influence of Leadership and Motivation on Employee Performance. Almana : Jurnal Manajemen Dan Bisnis, 4(2), 190-196. https://doi.org/10.36555/almana.v4i2.1352

24. Sahertian, P. (1998). Memanfaatkan hasil penilaian kinerja sebagai penentu kebijakan pengembangan karyawan. 27-40.

25. Sariyanti, W. (2012). Evaluasi kinerja pelayanan kesehatan pada puskesmas di kota semarang tahun 2012. Ejournal Undip.

26. Sedarmayanti. (2014). Manajemen Strategi. Refika Aditama.

27. Setiawan, Y. A. C., Pradhanawati, A., \& Budiatmo, A. (2014). Influence of Organizational Culture and Leadership on Employee Performance through Motivation as an Intervening Variable in PT. PLN (Persero) Semarang Area. Diponegoro Journal of Social and Politics, 1(11), 1-12.

28. Setiawan, Y. A., Pradhanawati, A., \& Budiatmo, A. (2014). Influence of Organizational Culture and Leadership on Employee Performance Through Motivation as an Intervening Variable in PT. PLN ( Persero ) Semarang Area. Jurnal Ilmu Administrasi Bisnis S1 Undip, 3(2), 120-131.

29. Stephen P. Robbins, T. A. J. (2013). Organizational Behavior : Edition 15. Pearson Prentice Hall.

30. Thoha, M. (2007). Perilaku Organisasi, Konsep Dasar dan Aplikasinya. Raja Grafindo Persada.

31. Van Dierendonck, D., Borrill, C., Haynes, C., \& Stride, C. (2004). Leadership Behavior and Subordinate Well-Being. Journal of Occupational Health Psychology, 9(2), 165-175. https://doi.org/10.1037/1076-8998.9.2.165

32. Wahyunanti, T., Ardiana, D. K. R., \& Ridwan, M. S. (2018). The Effect of Individual Characteristics, Employees Commitment, Job Stress on job satisfaction and employees performance in PT . Timbul Persada in Turban East Java. TRTF International Symposium Proceeding 2018 The, 103-107. 